\title{
Facultative habitat selection in Pacific tarpon Megalops cyprinoides as revealed by otolith Sr:Ca ratios
}

\author{
K. N. Shen ${ }^{2}$, C. W. Chang ${ }^{3,4, *}$, Y. Iizuka ${ }^{5}$, W. N. Tzeng ${ }^{1,2, *}$ \\ ${ }^{1}$ Department of Life Science, and ${ }^{2}$ Institute of Fisheries Science, College of Life Science, National Taiwan University, \\ Taipei, Taiwan 106, ROC \\ ${ }^{3}$ National Museum of Marine Biology and Aquarium, Pingtung, Taiwan 944, ROC \\ ${ }^{4}$ Institute of Marine Biodiversity and Evolutionary Biology, National Donghwa University, Hualien, Taiwan 974, ROC \\ ${ }^{5}$ Institute of Earth Sciences, Academia Sinica, Nankang, Taipei, Taiwan 115, ROC
}

\begin{abstract}
The Pacific tarpon Megalops cyprinoides is a euryhaline fish that is widely distributed in offshore waters of the tropical and subtropical Indo-Pacific Ocean. It spawns in offshore waters and the larvae drift with tidal currents before recruiting to estuarine nursery areas at $\sim 25$ to $30 \mathrm{~d}$ posthatching. Young Pacific tarpon are found in coastal waters, rivers, estuaries, inner bays, and mangrove areas. However, their age-specific migratory behavior and habitat selection are still unclear. The strontium (Sr) concentration in seawater is $\sim 100 \times$ higher than in fresh water, and the Sr:Ca ratios in fish otoliths are positively correlated with ambient salinity and are thus widely used in studying fish migration between seawater and freshwater environments. To understand the migratory environmental history of the Pacific tarpon, otolith Sr:Ca ratios of leptocephali collected from the estuary and sub-adults collected from both Tadu Creek and offshore waters on the west coast of Taiwan were examined using an electron probe microanalyzer (EPMA). Fish were aged by counting otolith annuli. The Sr:Ca ratios in leptocephalus otoliths were high $\left(7.4 \pm 0.03 \times 10^{-3}\right)$. However, the patterns of otolith $\mathrm{Sr}$ : Ca ratios in 1 to 3 yr old sub-adults were diverse and can be divided into 3 types: largely brackishwater residents, largely freshwater residents, and vagrants between brackish and fresh waters. Fish older than 4 to $5 \mathrm{yr}$ all return to the marine environment. This study demonstrates that habitat selection in the Pacific tarpon after the leptocephalus stage is facultative and that their migratory environmental history can be reconstructed from otolith Sr:Ca ratios.
\end{abstract}

KEY WORDS: Megalops cyprinoides $\cdot$ Pacific tarpon $\cdot$ Leptocephalus $\cdot$ Otolith $\cdot$ Sr:Ca ratio

Resale or republication not permitted without written consent of the publisher

\section{INTRODUCTION}

The family Megalopidae has 2 species of tarpon: the Pacific tarpon Megalops cyprinoides (Broussonet 1782) of the Indo-Pacific Ocean and the Atlantic tarpon Megalops atlanticus (Valenciennes 1847) of the Atlantic Ocean. Both species have a leptocephalus stage in their early life, as do other members of the Superorder Elopomorpha (Elopiformes, Albuliformes, Anguilliformes and Saccopharyngiformes) (Hulet \& Robin 1989). The tarpon is the most primitive of the Elopomorpha (Tsukamoto \& Okiyama 1997, Wang et al. 2003) and also the most ancestral among teleost fishes, as evi- denced by its morphological features and results of molecular study (Forey et al. 1996). Tarpon have a modified air bladder that allows them to inhale atmospheric oxygen and tolerate oxygen-poor environments (Wells et al. 2003). This enables them to live in polluted environments, and makes them useful as an indicator species for heavy stream pollution (Wang 2002). Although both species of tarpon are marine spawners, they can tolerate a wide range of salinities. After hatching, tarpon larvae are advected to an inshore nursery area 25 to 30 d later (Tzeng et al. 1998) and after metamorphosing, young tarpon are frequently found in rivers, bays, mangrove areas and even in the upper reaches 
of rivers (Merrick \& Schmida 1984, Tzeng \& Yu 1986, Coates 1987).

During spring and until late summer, large numbers of metamorphosing Pacific tarpon leptocephali are found schooling in the estuaries of western Taiwan (Tzeng et al. 2002b). However, little is known about their migratory history and habitat selection (Tsukamoto \& Okiyama 1993, 1997). As such, it is unknown whether Pacific tarpon obligate or facultative migratory fishes after the leptocephalus stage.

Fish migratory behavior and habitat selection usually change with life stage (Secor 1992). Such information can be retrieved using different means that include traditional census of tagged individuals (Zeller \& Russ 2000), advanced tagging and marking techniques, acoustic, archival and satellite tagging (Sedberry \& Loefer 2001) and use of natural markers such as chemical signatures within calcified structures like fish otoliths (Secor \& Rooker 2000, Tsukamoto \& Arai 2001, Tzeng et al. 2007).

Fish otoliths are primarily composed of calcium carbonate with minor organic matrices that are deposited on a daily basis (Pannella 1971, Campana \& Neilson 1985, Jones 1986), which permit the determination of daily fish age. The use of calcium (Ca) together with elements deposited in otolith increments enables the reconstruction of the past migratory environmental history of fish (Secor 1992, Bath et al. 2000). At least 31 elements have been found in fish otoliths (Campana 1999) and among these elements, strontium (Sr) and calcium are widely used in determining migratory history. Strontium ions have the same valence and similar ionic radius as calcium ions and are readily incorporated into aragonite otolith by substitution for calcium (Amiel et al. 1973). The $\mathrm{Sr}$ concentration in seawater is 100× higher than in fresh water (Campana 1999, Milton \& Chenery 2001), permitting the use of otolith $\mathrm{Sr}: \mathrm{Ca}$ ratios as a natural marker for examining the migratory environmental history, life history strategies and migratory behavior of diadromous fishes (Kalish 1990, Secor et al. 1995, Tzeng et al. 1997, Tsukamoto \& Arai 2001). The relationship between the Sr:Ca ratio in tarpon otolith and the ambient salinity after metamorphosis was validated by Chen et al. (2008) using wildcaught leptocephali reared in different salinities. Therefore, the migratory behavior and habitat selection of the Pacific tarpon can be reconstructed from otolith Sr:Ca profiles.

The aims of the present study were to use otolith microchemistry to clarify the migratory behavior of the Pacific tarpon between freshwater and marine habitats by analyzing temporal changes in Sr:Ca ratio in the otolith using an electron probe microanalyzer (EPMA). Fish age was determined by counting otolith annuli to evaluate whether habitat selection is age-specific.

\section{MATERIALS AND METHODS}

Sampling design. A total of 1106 tarpon leptocephali were collected from the estuary of Tadu Creek in 1998, 62 sub-adults were collected from the freshwater area of the lower ( $\mathrm{LT}, \mathrm{n}=54)$ and middle (MT, $\mathrm{n}=8$ ) reaches of Tadu Creek from 1998 to 1999, and 19 sub-adults were collected in the offshore waters adjacent to Tadu Creek in 2004 to 2005 (Fig. 1). The leptocephali were collected using a net set against the tidal current in the estuary, while the sub-adults from the lower and middle reaches of Tadu Creek were collected using a trammel net ( $50 \mathrm{~m}$ long $\times 1.5 \mathrm{~m}$ wide) with 3 layers of different mesh sizes $(15-20-15 \mathrm{~cm})$. Sub-adults were collected during the daytime monthly from March 1998 through March 1999. Two to 4 hauls from the middle and lower reaches of Tadu Creek were made each month. The sub-adults from offshore waters were collected using a gill net.

After collection, all specimens were preserved in ice in the field. The fork length of leptocephali and sub-adults and the body weight of sub-adults were measured to the nearest $0.1 \mathrm{~mm}$ and $0.01 \mathrm{~g}$. The number of fish collected and biological measurements can be seen in Table 1 . The gonads of sub-adult fish were visually examined to determine sex and maturation stage.

Otolith preparation for age determination. Sagittae, the biggest of the 3 pairs of otoliths, were removed from the sacculus of the inner ear. The right sagittal otolith was cleaned with distilled water, air dried, embedded in Epofix resin, ground and then polished along the sagittal plane with $0.05 \mu \mathrm{m}$ alumina powder until the primordium was exposed. The annuli were

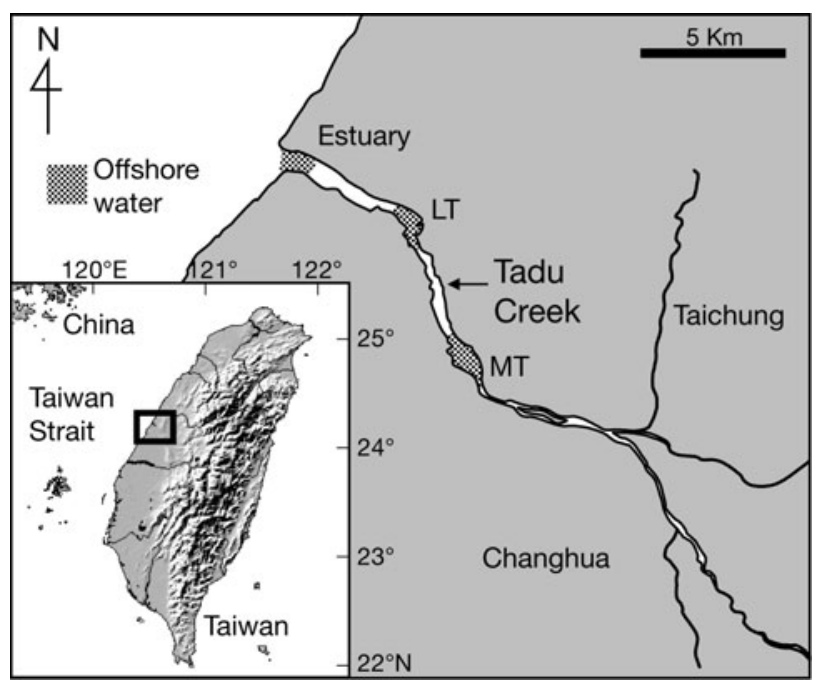

Fig. 1. Sampling locations (dotted areas) for Pacific tarpon Megalops cyprinoides in the estuary, the lower (LT) and middle (MT) reaches, and the offshore waters adjacent to Tadu Creek in central Taiwan 
examined under a microscope with a black background to determine age. Annual rings, which are discernible as shown in Fig. 2a, were validated by counting the number of otolith daily increments between the metamorphosis check and the first annulus during the period from recruitment to the first winter (Fig. 2b). The annulus in each otolith was counted by 2 different readers. Previous studies have shown that the otolith growth increment in Pacific tarpon is deposited daily (Tsukamoto \& Okiyama 1993, Chen \& Tzeng 2006); thus, the daily growth increments in leptocephali otoliths were counted to determine the marine larval duration before estuarine arrival. In total, random subsamples of 88 leptocephali and 81 sub-adults collected from fresh water $(\mathrm{n}=62)$ and offshore waters $(\mathrm{n}=19)$ were aged.

Measurement of otolith $\mathrm{Sr}: \mathrm{Ca}$ ratios. The temporal pattern of Sr:Ca ratios (wt \%) along the otolith transect was used to evaluate the environmental history of each Pacific tarpon, and the measurement procedures were similar to those used by Tzeng et al. (2002a, 2003). For comparison, 5 leptocephali were randomly selected for $\mathrm{Sr}$ :Ca ratio analysis, while the 81 sub-adults collected from freshwater $(n=62)$ and offshore $(n=19)$ habitats were all used in age determination and otolith $\mathrm{Sr}: \mathrm{Ca}$
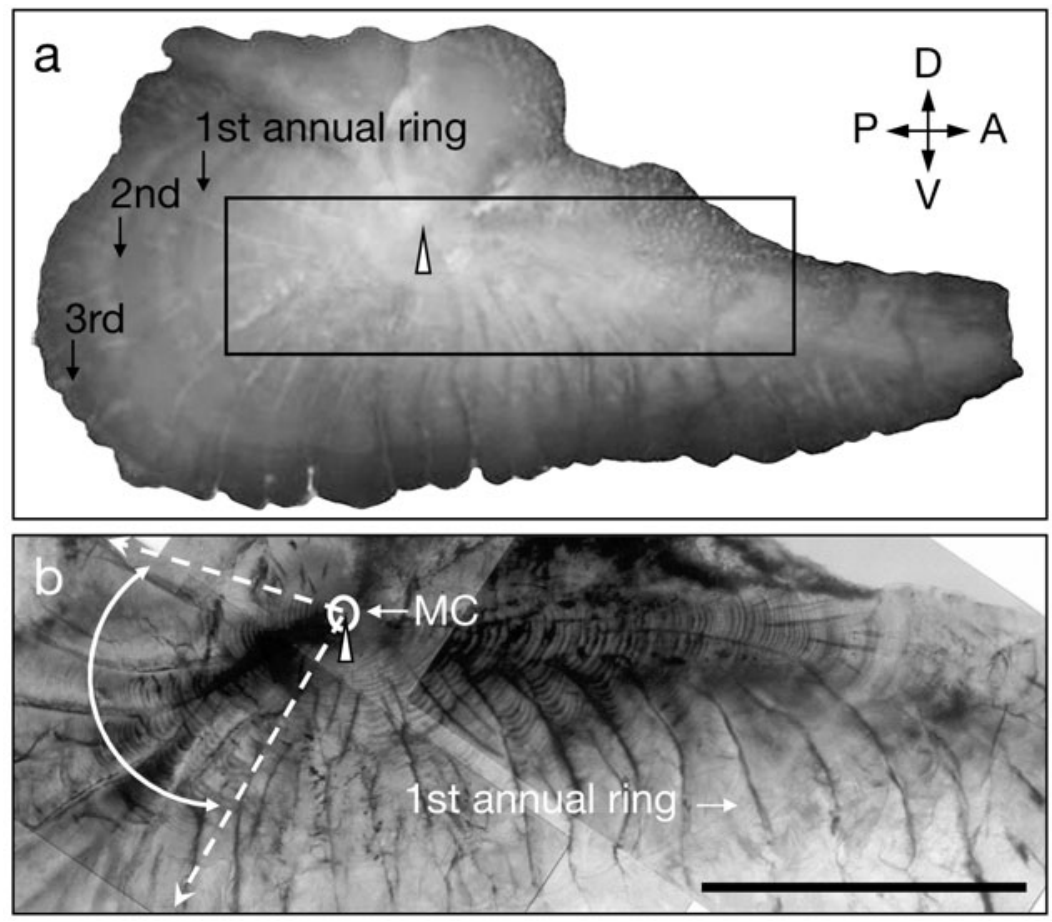

Fig. 2. Megalops cyprinoides. External features of the otolith and (a) annual rings under reflected light, and (b) daily growth increments and annual rings under transmitted light after polishing of a sub-adult (390 $\mathrm{mm}$ fork length). ( $\Delta$ ) Otolith primordium, MC: metamorphosis check. The area within the dashed lines indicates the location of Sr:Ca ratio analysis. A: anterior, P: posterior, D: dorsal, V: ventral. Scale bar $=1 \mathrm{~mm}$ ratio analyses. The otolith $\mathrm{Sr}$ :Ca ratios of the sub-adults were measured along the shorter posterior axis of the otolith (Fig. 2b). Otolith Sr and Ca concentrations were measured using an EPMA (JXA-8900R, JEOL) at an interval of $10 \mu \mathrm{m}$ from the primordium to the otolith edge, with an electron beam size of $5 \times 4 \mu^{2}$ rectangle, and accelerating voltage and probe current set at $15 \mathrm{kV}$ and $5 \mathrm{nA}$, respectively. Strontianite $\left(\left[\mathrm{Sr}_{0.95} \mathrm{Ca}_{0.05}\right]\right.$ $\left.\mathrm{CO}_{3}\right)$ and aragonite $\left(\mathrm{CaCO}_{3}\right)$ were used as standards for the calibration of $\mathrm{Sr}$ and $\mathrm{Ca}$ concentration in the otolith.

Life history determination and data analysis. An average $\mathrm{Sr}$ : Ca ratio of $\leq 4 \times 10^{-3}$ was considered as the criterion to discriminate freshwater from brackishwater environments of the tarpon, as validated by a salinity control experiment with tarpon reared at a salinity of 0 by Chen et al. (2008). This criterion was also supported by the average $\mathrm{Sr}$ :Ca ratio of $3.8 \pm 0.54 \times 10^{-3}$ calculated from the Sr:Ca ratios in the otolith edge of 62 wild sub-adult $\mathrm{Pa}-$ cific tarpon caught in the freshwater reaches of Tadu Creek. The average Sr:Ca ratio range of tarpon reared in salinities of 10 and 35 were $6 \times 10^{-3}$ to $8 \times 10^{-3}$ and $7 \times$ $10^{-3}$ to $11 \times 10^{-3}$, respectively (Chen et al. 2008). Average Sr: Ca ratios $>8 \times 10^{-3}$ were considered as the criterion separating exclusively marine and brackishwater environments. The average $\mathrm{Sr}$ :Ca ratio $(8.6 \pm$ $0.98 \times 10^{-3}$ ) in the otolith edge of 19 offshore sub-adults supports this criterion. Thus, tarpon with otolith $\mathrm{Sr}: \mathrm{Ca}$ ratios $\leq 4 \times$ $10^{-3}$ were considered as freshwater residents, those with $\mathrm{Sr}$ :Ca ratios $>4 \times 10^{-3}$ and $\leq 8 \times 10^{-3}$ were regarded as brackishwater residents, and those with $\mathrm{Sr}: \mathrm{Ca}$ ratios $>8 \times 10^{-3}$ were considered as seawater residents. Differences in age distribution between habitats were tested for significance using the KolmogorovSmirnov 2-sample test.

\section{RESULTS}

\section{Length, weight and age of tarpon in different habitats}

The fork lengths of 88 randomly selected Pacific tarpon leptocephali from the Tadu Creek estuary ranged from 21.9 to $30.2 \mathrm{~mm}$. The fork length and body weight of 62 sub-adult tarpon collected in both the lower (LT) and middle (MT) reaches of Tadu Creek ranged from 174.4 to $343.7 \mathrm{~mm}$ and 69.38 to $558.77 \mathrm{~g}$, while those for the 19 tarpon collected in waters offshore of Tadu Creek ranged 
Table 1. Megalops cyprinoides. Range and mean $( \pm \mathrm{SD})$ fork length, body weight and age by sampling site and life stage of Pacific tarpon from the Tadu Creek system and adjacent offshore waters, Taiwan. n: sample size; N/A: not available

\begin{tabular}{|c|c|c|c|c|c|c|c|c|}
\hline \multirow{2}{*}{ Site } & \multirow{2}{*}{ Life stage } & \multirow{2}{*}{$\mathrm{n}$} & \multicolumn{2}{|c|}{ — Fork length (mm) — } & \multicolumn{2}{|c|}{ — Body weight $(\mathrm{g})-$} & \multirow[b]{2}{*}{ Range } & \multirow{2}{*}{$\begin{array}{l}\text { Age } \\
\text { Mean } \pm \text { SD }\end{array}$} \\
\hline & & & Range & Mean $\pm \mathrm{SD}$ & Range & Mean \pm SD & & \\
\hline Estuary & Leptocephalus & 88 & $21.9-30.2$ & $25.4 \pm 1.7$ & N/A & N/A & $18-34 \mathrm{~d}$ & $25.2 \pm 4.7 \mathrm{~d}$ \\
\hline $\begin{array}{l}\text { Lower and } \\
\text { middle reaches }\end{array}$ & $\begin{array}{l}\text { Young to } \\
\text { sub-adult }\end{array}$ & 62 & $174.4-343.7$ & $251.7 \pm 28.4$ & $69.38-558.77$ & $227.88 \pm 79.34$ & $1-3 \mathrm{yr}$ & $2.2 \pm 0.6 \mathrm{yr}$ \\
\hline $\begin{array}{l}\text { Adjacent } \\
\text { offshore }\end{array}$ & Sub-adult & 19 & $276.6-435.1$ & $368.2 \pm 41.1$ & $286.82-1145.20$ & $780.02 \pm 243.99$ & $2-5 \mathrm{yr}$ & $4.1 \pm 0.9 \mathrm{yr}$ \\
\hline
\end{tabular}

from 276.6 to $435.1 \mathrm{~mm}$ and 286.82 to $1145.20 \mathrm{~g}$, respectively. The newly recruited leptocephali $(n=88)$ ranged from 18 to 34 d old, while sub-adults collected from Tadu Creek and from offshore waters were estimated to be 1 to 3 and 2 to 5 yr old, respectively (Table 1 ).

Temporal changes in otolith Sr:Ca ratios of leptocephali and sub-adults (ages 1 to 3 ) in fresh water

Sr:Ca ratios from the primordium to the otolith edge of 5 newly recruited leptocephali ranged from $5.1 \times$ $10^{-3}$ to $10.9 \times 10^{-3}$, with a mean of $7.4 \pm 0.03 \times 10^{-3}$ (Fig. 3), indicating that they lived in a marine and brackishwater environment before estuarine arrival. $\mathrm{Sr}$ :Ca ratios from the primordium to the otolith edge of 5 sub-adults collected from the freshwater lower reach of Tadu Creek (LT) also ranged from $5 \times 10^{-3}$ to $11 \times$ $10^{-3}$ in the leptocephalus stage (Fig. 4). After metamorphosis, however, the patterns of $\mathrm{Sr}: \mathrm{Ca}$ ratios varied greatly and can be classified into 3 types of migration behavior: Type I: largely brackishwater residents with $\mathrm{Sr}$ :Ca ratios that fluctuated mostly between $4 \times 10^{-3}$ and $8 \times 10^{-3}$, indicating stay in a brackishwater envi-

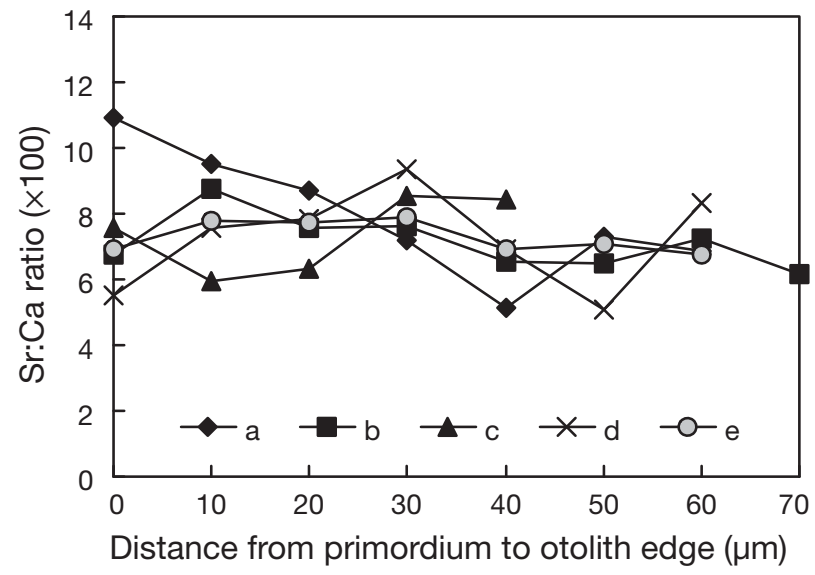

Fig. 3. Megalops cyprinoides. Temporal changes in otolith Sr:Ca ratios of 5 newly recruited leptocephali collected from Tadu Creek estuary. a-e: sizes in mm fork length (a: 25.8, b: 26.5, c: 25.2 , d: 26.0 , and e: 24.5$)$ ronment after metamorphosis but with possible occasional invasion of marine or fresh waters (exhibited by 12 out of 54 ind.; Fig. 4a,b); Type II: largely freshwater residents, with $\mathrm{Sr}$ : Ca ratios mostly $<4 \times 10^{-3}$, indicating stay in fresh water after metamorphosis but with possible occasional invasion of brackish waters (exhibited by 34 out of 54 ind.; Fig. 4c,d); and Type III: vagrants that migrated between fresh and brackish waters for longer periods after metamorphosis (exhibited by 8 out of 54 ind.; Fig. 4e). Tarpon collected in the middle reach of Tadu Creek (MT), however, did not have Type I residents. Out of 8 ind., 6 were Type II (e.g. Fig. 5a,b) and 2 were Type III vagrants (Fig. 5c,d).

\section{Temporal changes in otolith Sr:Ca ratios of sub-adults (ages 2 to 5 ) in offshore waters}

Otolith Sr:Ca ratios from the primordium to the edge for 18 of the 19 tarpon collected in waters offshore of Tadu Creek ranged from $4.8 \times 10^{-3}$ to $12.8 \times 10^{-3}$ in the leptocephalus stage, except for some individuals where the marine larval stage was not measured. The tarpon caught in offshore waters were all Type III because after 2 to $3 \mathrm{yr}$, most fish gradually moved to the marine environment regardless of their earlier migratory type. For example, tarpon of Type I for the first 2 yr might gradually go back to the sea (Fig. 6a-c) or move to fresh water for a period before finally going back to the sea (Fig. 6d,e). Fig. 6f-o are examples of Type II tarpon for the first 1 to 3 yr that stayed in brackish water for another 1 to $2 \mathrm{yr}$ and then went back to seawater (Fig. $6 \mathrm{f}-\mathrm{n}$ ), except for 1 ind. that went back to the sea for a period and then back to fresh water before finally going to brackish and seawater (Fig. 6o). Fig. 6p-r are examples of Type III tarpon for the first year. One individual frequently migrated between fresh and brackish water during its first year, and did not move to seawater until its 4th year (Fig. 6p). Another 2 ind. were also vagrants between fresh and brackish waters during their first year that stayed in the freshwater environment for another 1 to 3 yr before finally moving back to seawater quickly (Fig. 6q,r). 

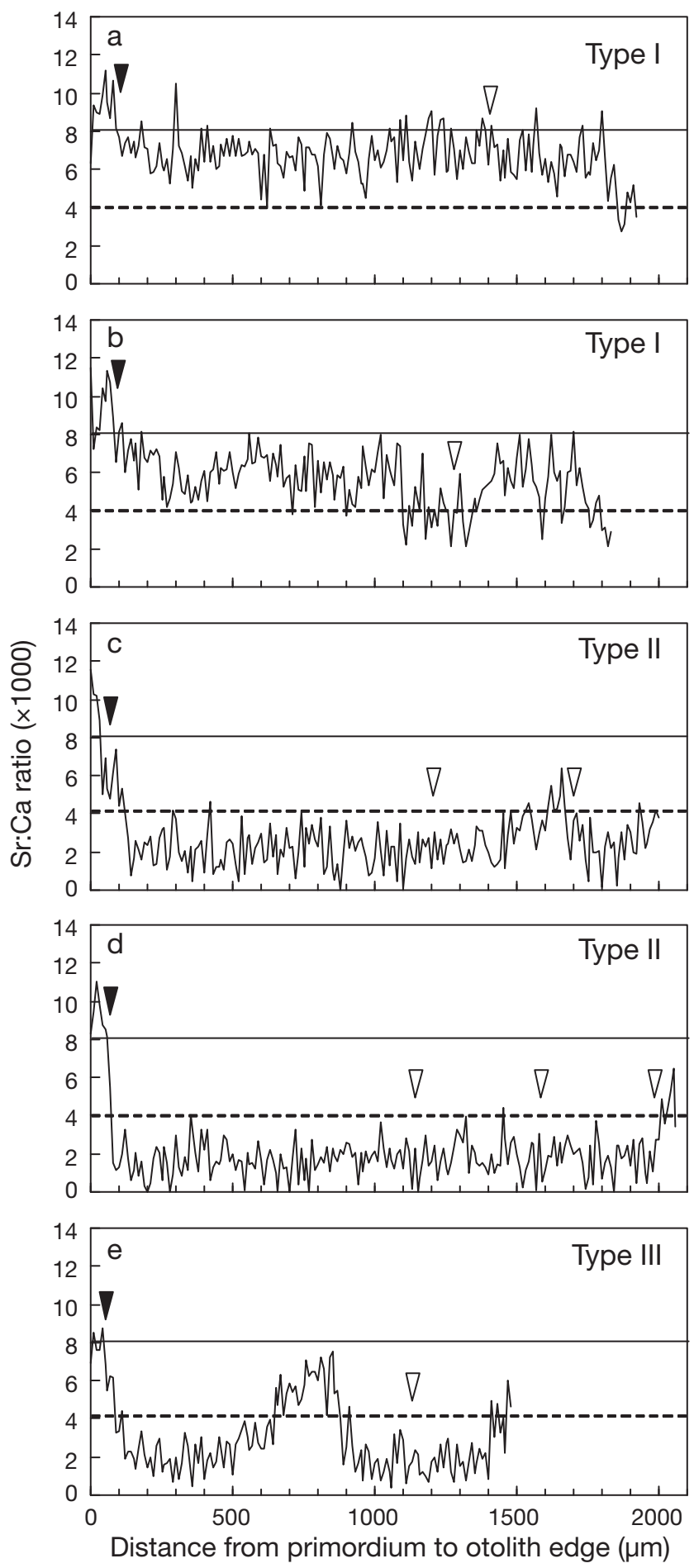

Fig. 4. Megalops cyprinoides. Temporal changes in otolith Sr:Ca ratios of young Pacific tarpon collected in the freshwater lower reach of Tadu Creek (LT in Fig. 1). (a) 208.3, (b) 190, (c) 225.5, (d) 287.9, and (e) $174.9 \mathrm{~mm}$ fork length. (V) Metamorphosis check; $(\nabla)$ annual rings. The freshwater-brackishwater boundary (dashed lines) was set at $4 \times 10^{-3}$, while the brackishseawater boundary (solid lines) was $8 \times 10^{-3}$. Type I: brackishwater residents; Type II: freshwater residents; Type III: vagrants between brackish and fresh waters
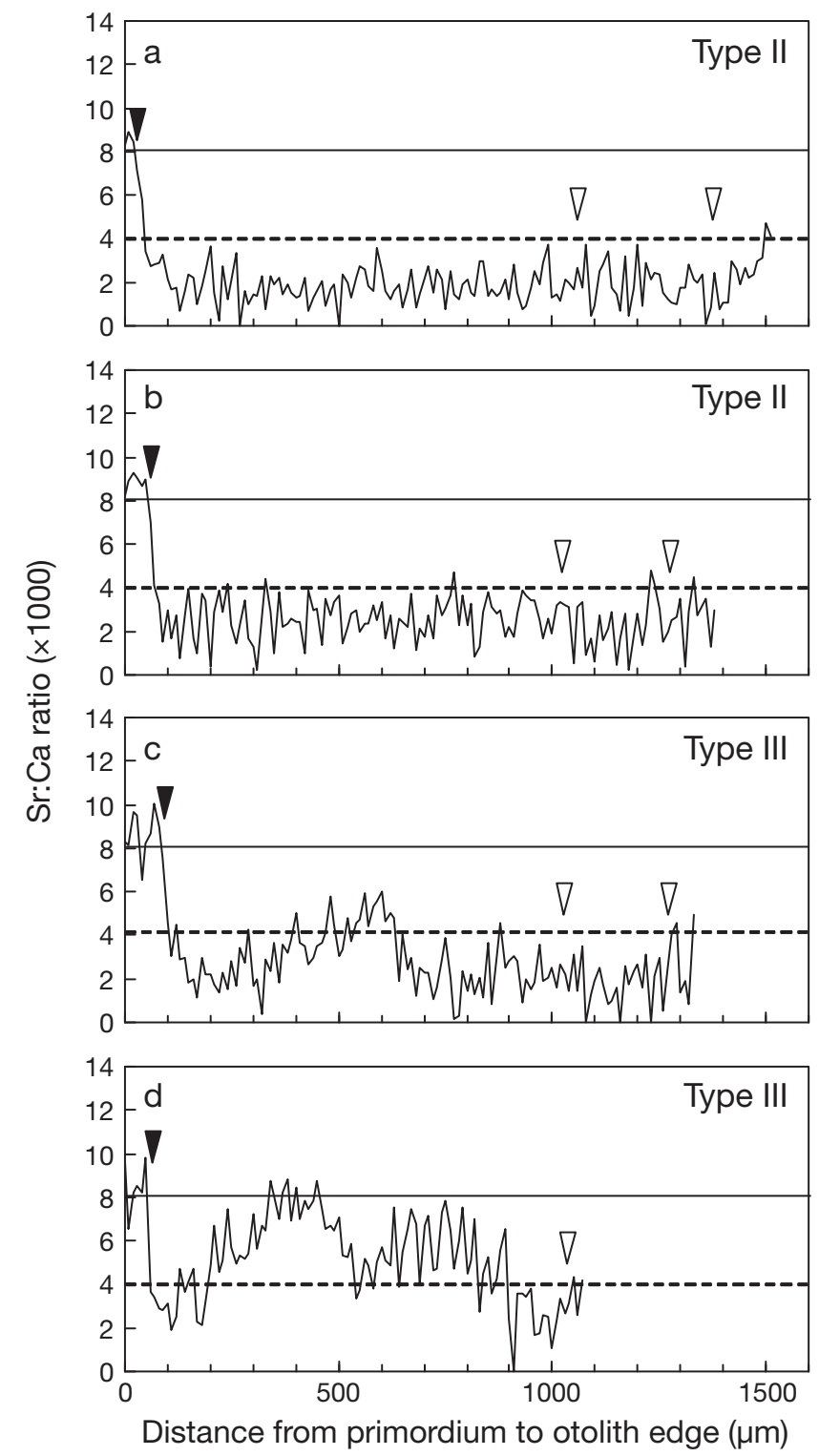

Fig. 5. Megalops cyprinoides. Temporal changes in otolith Sr:Ca ratios of young Pacific tarpon collected in the middle reach of Tadu Creek (MT in Fig. 1). (a) 264.1, (b) 252.9, (c) 247.1, and (d) $226.3 \mathrm{~mm}$ fork length. ( $\mathbf{V}$ ) Metamorphosis check; $(\nabla)$ annual rings. The freshwater-brackishwater boundary (dashed lines) was set at $4 \times 10^{-3}$, while the brackishwaterseawater boundary (solid lines) was $8 \times 10^{-3}$. Type I: brackishwater residents; Type II: freshwater residents; Type III: vagrants between brackish and fresh waters

\section{Age-specific habitat selection and migratory behavior}

Age $1+$ tarpon constituted $9.7 \%$ of the total specimens collected in the freshwater environment of Tadu Creek, but no age 1+ tarpon were found offshore (Fig. 7a). One age $2+$ tarpon was found offshore $(5.3 \%$ of the total catch for offshore sampling) but most fishes 


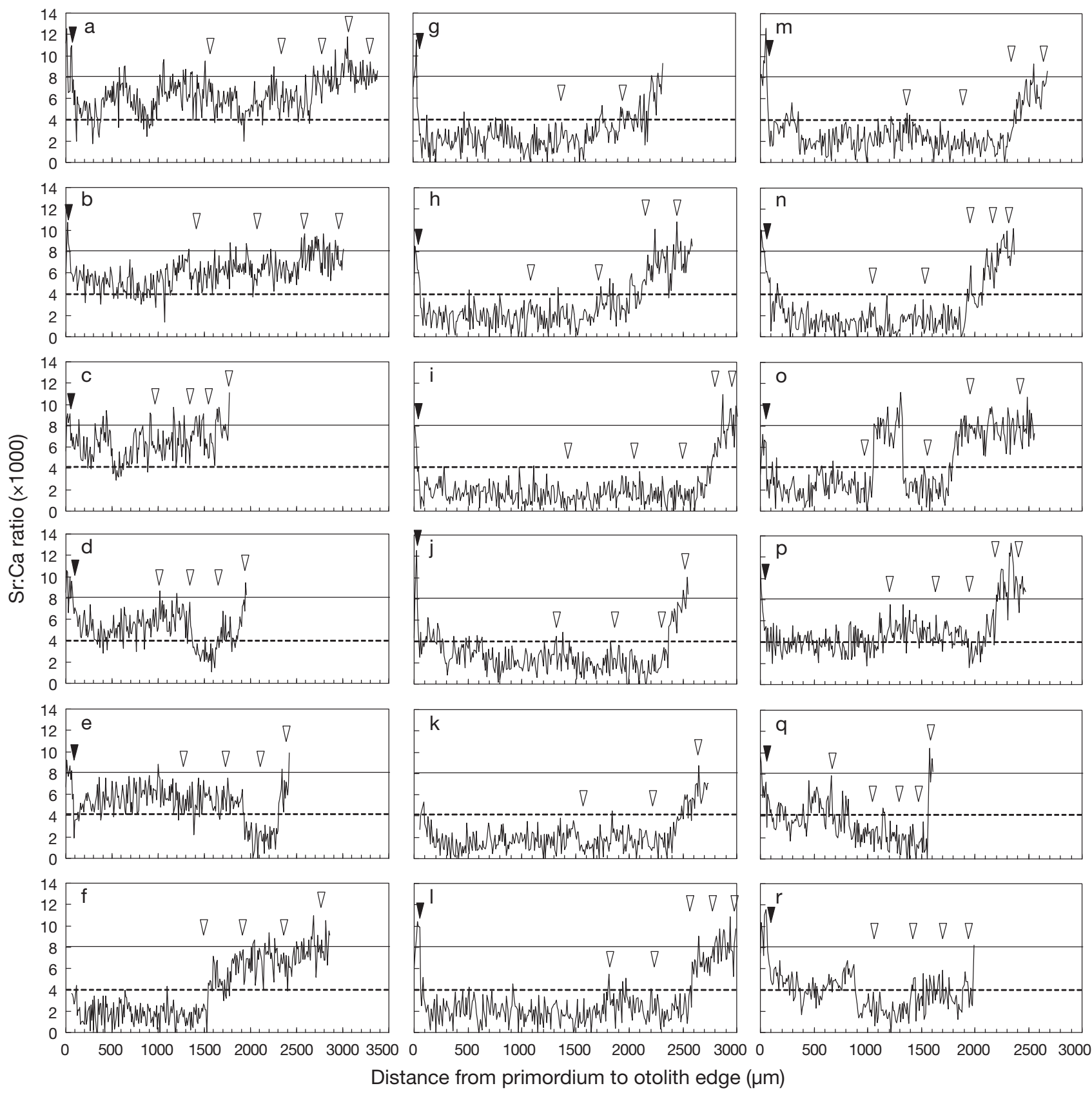

Fig. 6. Megalops cyprinoides. Temporal changes in otolith Sr:Ca ratios of sub-adult Pacific tarpon collected in the waters offshore of Tadu Creek. (a) 377.3, (b) 407.2, (c) 364.5, (d) 347.2, (e) 391.9, (f) 419.3, (g) 300.2, (h) 391.2, (i) 378.3, (j) 345.7, (k) 276.1, (l) 435.1, (m) 365.3, (n) 401.8, (o) 349.5, (p) 384.3, (q) 405.1, and (r) $346.7 \mathrm{~mm}$ fork length. (V) Metamorphosis check; ( $\nabla$ ) annual rings. The freshwater-brackishwater boundary (dashed lines) was set at $4 \times 10^{-3}$, while the brackishwater-seawater boundary (solid lines) was $8 \times 10^{-3}$

stayed in the fresh water $(66.1 \%$ of specimens collected in fresh water) of Tadu Creek. At age $3+, 24.2 \%$ of tarpon remained in fresh water while $10.5 \%$ moved offshore. All tarpon moved offshore at ages $4+$ and $5+$. The frequency distributions of age-specific habitat selection differed significantly between fresh and offshore waters (Kolmogorov-Smirnov $D=0.8421, \mathrm{p}<0.001$ ).
The accumulated frequency of freshwater residents (Type II) was higher (58\%) than for brackishwater residents (Type I) $(27.2 \%)$ and for vagrants (Type III) $(14.8 \%)$ at age $1+$. The accumulated frequencies of Type II and Type I gradually decreased with age until age $3+$ but gradually increased with age for Type III. At age 4+ and 5+, all tarpon were Type III (Fig. 7b). 

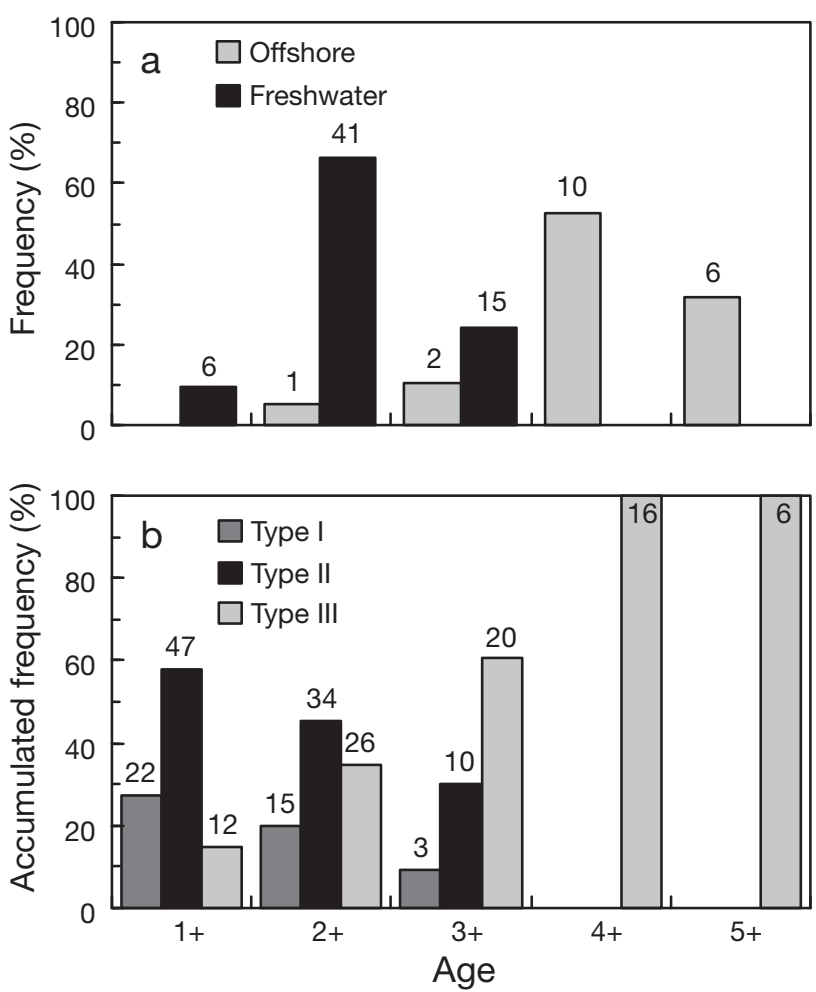

Fig. 7. Megalops cyprinoides. (a) Frequency distributions of age-specific habitat use (b) and the accumulated frequencies of age-specific migratory patterns (Types I, II and III refer to Fig. 4). Numbers above bars are sample sizes

\section{DISCUSSION}

\section{Migratory history reconstruction from otolith Sr:Ca ratios}

Fish movements between marine, estuarine, and freshwater habitats have been reconstructed from temporal changes in otolith Sr:Ca ratios for anguillid eels (Japanese eel Anguilla japonica: Tzeng \& Tsai 1994, Tzeng et al. 2002a, 2003; European eel Anguilla anguilla: Tzeng et al. 1997; American eel Anguilla rostrata (Jessop et al. 2002, 2004) striped bass Morone saxitilis (Secor \& Piccoli 1996) and amphidromous goby Sicyopterus japonicus (Shen \& Tzeng 2002). The incorporation of Sr into the otolith is a complex biogeochemical process which is influenced by both intrinsic and exogenous factors (Fowler et al. 1995) as well as the crystalline structure of the otolith (Tzeng et al. 2007). Although the ambient temperature may affect the Sr:Ca ratio of the otolith (Townsend et al. 1992, Elsdon \& Gillanders 2004), the effect of temperature on otolith Sr:Ca ratios in Pacific tarpon was found to be negligible (Tzeng 1996, Chen et al. 2008). Ambient salinity is the main factor affecting otolith $\mathrm{Sr}$ :Ca ratios in reared leptocephali (Chen \& Tzeng 2006, Chen et al. 2008). The Sr:Ca ratios used to judge Pacific tarpon migra- tions between freshwater, brackishwater and offshore environments were similar to those used for other fish species. For example, Jessop et al. $(2002,2004)$ divided the American eel into freshwater and estuarine residents when otolith $\mathrm{Sr}$ : Ca ratios were $<4 \times 10^{-3}$ and $>5 \times 10^{-3}$, with the intermediate values representing a change in habitat. Tzeng et al. (2002a, 2003) used a Sr:Ca ratio of $4 \times 10^{-3}$ in the otoliths of the Japanese eel as a criterion to distinguish freshwater and seawater contingents. Shiao et al. (2003) also used the upper limit of $4 \times 10^{-3}$ as a criterion to separate the Japanese eel and the giant mottled eel Anguilla marmorata into freshwater, estuarine or marine residents. Kawakami et al. (1998) reported $\mathrm{Sr}: \mathrm{Ca}$ ratios in Japanese eel elvers that averaged $\sim 4.5 \times 10^{-3}$ in fresh water and $8.3 \times 10^{-3}$ in seawater. Chang et al. (2004), however, used the $95 \%$ CI of the mean Sr:Ca ratio at the estuarine check of the adult mullet otolith $\left(3 \times 10^{-3}\right.$ and $7 \times$ $10^{-3}$ ) as the criterion to distinguish habitat change between fresh water, brackish water and offshore high-salinity water for the grey mullet Mugil cephalus. The similarities in criteria used for different fishes living in the same environment suggest that plasma ionic homeostasis may occur for different fishes in certain environments. The minor differences observed among the studies may result from differences in analytical methods, sampling sites and species (Jessop et al. 2002).

\section{Facultative migratory behavior and} euryhalinity in sub-adult Pacific tarpon

The tarpon, like many other estuarine-dependent marine fishes, recruit to an estuarine nursery habitat during the age $0+$ period of their life history, but the migratory behavior of young and sub-adult tarpon is not yet fully understood. After the reconstruction of the migratory environmental history of the Pacific tarpon using Sr:Ca ratios, all 3 migratory types were found in the lower reach of the freshwater stream, but Type I was not found in the middle reach of Tadu Creek. This means that Type I individuals preferred to stay in brackish water, might move to the lower reaches of the freshwater stream, but would not get into the middle reach. In contrast, Type II individuals preferred the freshwater environment, and might stay in either low or middle reaches of the Creek, suggesting higher adaptability to the freshwater environment. Type III individuals had the ability to migrate between brackish and freshwater environments within age $0+$, enabling them to select a wider range of habitats. The sub-adult tarpon caught in offshore waters all had higher Sr:Ca ratios at the otolith edge, but their past migratory history shows that they fit the 3 migratory behaviors of the tarpon in the creek. Most tarpon (53\%) stayed in a freshwater en- 
vironment for 1 to $3 \mathrm{yr}$, but some tarpon still stayed in a brackishwater environment for 2 to 3 yr before moving offshore or to a freshwater environment, or migrated between freshwater and brackishwater environments. Therefore, the migratory behavior of tarpon is highly variable and facultative. Tarpon tended to stay in fresh water at ages $0+$ to $1+$ but as age increased, the proportion of fish inhabiting fresh water decreased and no fish at age $4+(n=16)$ or older $(n=6)$ inhabited fresh water.

Tarpon occupy a high trophic level and are predominately piscivorous. Atlantic tarpon, for example, prey on mullet juveniles during their migrations along the Caribbean coast from March to July (Catano \& Garzon-Ferreira 1994). Pacific tarpon also prey on mullet in both brackish and fresh waters and on milkfish in culture ponds of Taiwan (Tzeng \& Yu 1986), suggesting a euryhaline habit.

\section{Where do the mature Pacific tarpon go?}

Mature Atlantic tarpon are usually $>1000 \mathrm{~mm}$ in standard length and around 10 yr old (Crabtree et al. 1997), with 1 female Atlantic tarpon being reported to be 2032 mm in standard length (Wade 1962). Few Pacific tarpon in Taiwan are $>600 \mathrm{~mm}$ in total length (TL), but a Pacific tarpon of $1500 \mathrm{~mm}$ TL was recorded in Bangladesh (Rahman 1989). All tarpon collected in the present study were immature because no obvious gonads were found. The newly recruited leptocephalus had daily ages ranging from 18 to $34 \mathrm{~d}$, suggesting that the spawning ground was nearby. In addition, adult Pacific tarpon may go deeper for spawning just like the Atlantic tarpon (90 to $1400 \mathrm{~m}$ ) (Wade 1962, Crabtree et al. 1992) and other members of the Superorder Elopomorpha (Tsukamoto et al. 2002). The 19 sub-adults collected offshore from Tadu Creek were estimated to be 2 to $5 \mathrm{yr}$ old based on the examination of annual rings in their otoliths. While our study does not directly answer the question of where mature Pacific tarpon live, the high Sr:Ca ratios in the leptocephalus stage and the spawning behavior of its congeners support the hypothesis of deep-sea spawning in offshore waters.

In conclusion, we found that (1) after metamorphosing from the leptocephalus to the juvenile stage, Pacific tarpon found in Tadu Creek could inhabit fresh and brackish waters or migrate facultatively between these habitats, (2) at age 0+, tarpon preferentially occupy fresh water, (3) tarpon gradually move back to marine waters after $4 \mathrm{yr}$ of age, indicating euryhaline behavior and facultative habitat selection by subadults, and (4) the spawning migration of the tarpon is still unknown but the high Sr:Ca ratio during the leptocephalus stage supports the hypothesis of offshore spawning by Pacific tarpon.
Acknowledgement. We thank H. Y. Teng for specimen sorting and aging, and N. J. Leander, B. M. Jessop and several anonymous reviewers for comments on the early draft of the manuscript. This study was conducted with the financial support of the National Science Council, Republic of China (Project No. NSC 95-2313-B002-057).

\section{LITERATURE CITED}

Amiel AJ, Friedman GM, Miller DS (1973) Distribution and nature of incorporation of trace elements in modern aragonite corals. Sedimentology 20:47-64

> Bath GE, Thorrold SR, Jones CM, Campana SE, McLaren JW, Lam JWH (2000) Strontium and barium uptake in aragonitic otoliths of marine fish. Geochim Cosmochim Acta 64: 1705-1714

> Campana SE (1999) Chemistry and composition of fish otoliths: pathways, mechanisms, and applications. Mar Ecol Prog Ser 188:263-297

> Campana SE, Neilson JD (1985) Microstructure of fish otoliths. Can J Fish Aquat Sci 42:1014-1032

Catano S, Garzon-Ferreira J (1994) Tropic ecology of the tarpon Megalops atlanticus (Pisces: Megalopidae) in the area of Cienaga Grande de Santa Marta, Colombian Caribbean. Rev Biol Trop 42:673-684

> Chang CW, Iizuka Y, Tzeng WN (2004) Migratory environmental history of the grey mullet Mugil cephalus as revealed by otolith Sr:Ca ratios. Mar Ecol Prog Ser 269: $277-288$

Chen HL, Tzeng WN (2006) Daily growth increment formation in otoliths of Pacific tarpon Megalops cyprinoides during metamorphosis. Mar Ecol Prog Ser 312:255-263

Chen HL, Shen KN, Chang CW, Iizuka Y, Tzeng WN (2008) Effects of water temperature, salinity and feeding regimes on metamorphosis, growth and otolith $\mathrm{Sr}: \mathrm{Ca}$ ratios of Megalops cyprinoides leptocephali. Aquat Biol 3:41-50

$>$ Coates D (1987) Observations on the biology of tarpon, Megalops cyprinoides (Broussonet) (Pisces: Megalopidae), in the Sepik River, northern Papua New Guinea. Aust J Mar Freshwater Res 38:529-535

Crabtree RE, Cyr EC, Bishop RE, Falkenstein LM, Dean JM (1992) Age and growth of tarpon, Megalops atlanticus, larvae in the eastern Gulf of Mexico with notes on relative abundance and probable spawning areas. Environ Biol Fishes 35:361-370

Crabtree RE, Cyr EC, Chaverri DC, McLarney WO, Dean JM (1997) Reproduction of tarpon, Megalops atlanticus, from Florida and Costa Rican waters and notes on their age and growth. Bull Mar Sci 61:271-285

Elsdon TS, Gillanders BM (2004) Fish otolith chemistry influenced by exposure to multiple environmental variables. J Exp Mar Biol Ecol 313:269-284

Forey PL, Littlewood DTJ, Ritchie P, Meyer A (1996) Interrelationships of elopomorph fishes. In: Stiassny MLJ, Parenti LR, Johnson GD (eds) Interrelationships of fishes. Academic Press, San Diego, CA, p 175-191

Fowler AJ, Campana SE, Jones CM, Thorrold SR (1995) Experimental assessment of the effect of temperature and salinity on elemental composition of otoliths using laser ablation ICPMS. Can J Fish Aquat Sci 52:1431-1441

Hulet WH, Robin CR (1989) The evolutionary significance of the leptocephalus larva. In: Bohlke, EB (ed) Fishes of the western North Atlantic. Sears Foundation for Marine Research (Memoir No. I, Part 9, Vol 2), New Haven, CT, p 669-677

Jessop BM, Shiao JC, Iizuki Y, Tzeng WN (2002) Migratory 
behaviour and habitat use by American eels Anguilla rostrata as revealed by otolith microchemistry. Mar Ecol Prog Ser 233:217-229

> Jessop BM, Shiao JC, Iizuki Y, Tzeng WN (2004) Variation in the annual growth, by sex and migration history, of silver American eels Anguilla rostrata. Mar Ecol Prog Ser 272: 231-244

Jones CM (1986) Determining age of larval fish with the otolith increment technique. Fish Bull US 84:91-103

Kalish JM (1990) Use of otolith microchemistry to distinguish progeny of sympatric anadromous and non-anadromous salmonids. Fish Bull US 88:657-666

Kawakami Y, Mochioka N, Morishita K, Tajima T, Nakagawa H, Toh H, Nakazono A (1998) Factors influencing otolith strontium/calcium ratios in Anguilla japonica elvers. Environ Biol Fishes 52:299-303

Merrick JR, Schmida GE (1984) Australian freshwater fishes biology and management. Griffin Press, Netley, SA

Milton DA, Chenery SR (2001) Sources and uptake of trace metals in otoliths of juvenile barramundi (Lates calcarifer). J Exp Mar Biol Ecol 264:47-65

Pannella G (1971) Fish otoliths: daily growth layers and periodical patterns. Science 173:1124-1127

Rahman AKA (1989) Freshwater fishes of Bangladesh. Zoological Society of Bangladesh. Department of Zoology, University of Dhaka, p 364

Secor DH (1992) Application of otolith microchemistry analysis to investigate anadromy in Chesapeake Bay striped bass Morone saxatilis. Fish Bull (Wash DC) 90:798-806

Secor DH, Piccoli PM (1996) Age- and sex-dependent migrations of striped bass in the Hudson River as determined by chemical microanalysis of otoliths. Estuaries 19:778-793

Secor DH, Rooker JR (2000) Is otolith strontium a useful scalar of life cycles in estuarine fishes? Fish Res 46:359-371

Secor DH, Henderson-Arzapalo A, Piccoli PM (1995) Can otolith microchemistry chart patterns of migration and habitat utilization in anadromous fishes? J Exp Mar Biol Ecol 192:15-33

Sedberry GR, Loefer JK (2001) Satellite telemetry tracking of swordfish, Xiphias gladius, off the eastern United States. Mar Biol 139:355-360

Shen KN, Tzeng WN (2002) Formation of a metamorphosis check in otoliths of the amphidromous goby Sicyopterus japonicus. Mar Ecol Prog Ser 228:205-211

Shiao JC, Iizuka Y, Chang CW, Tzeng WN (2003) Disparities in habitat use and migratory behavior between tropical eel Anguilla marmorata and temperate eel A. japonica in four Taiwanese rivers. Mar Ecol Prog Ser 261:233-242

Townsend DW, Radtke RL, Corwin S, Libby DA (1992) Strontium:calcium ratios in juvenile Atlantic herring Clupea harengus L. otoliths as a function of water temperature. J Exp Mar Biol Ecol 160:131-140

Tsukamoto K, Arai T (2001) Facultative catadromy of the eel Anguilla japonica between freshwater and seawater habitats. Mar Ecol Prog Ser 220:265-276

Tsukamoto Y, Okiyama M (1993) Growth during the early life history of the Pacific tarpon, Megalops cyprinoides. Jpn J Ichthyol 39:379-386

Tsukamoto Y, Okiyama M (1997) Metamorphosis of the

Editorial responsibility: Matthias Seaman, Oldendorf/Luhe, Germany
Pacific tarpon, Megalops cyprinoides (Elopiformes, Megalopidae) with remarks on development patterns in the Elopomorpha. Bull Mar Sci 60:23-36

Tsukamoto K, Aoyama J, Miller MJ (2002) Migration, speciation and the evolution of diadromy in anguillid eels. Can J Fish Aquat Sci 59:1989-1998

$>$ Tzeng WN (1996) Effects of salinity and ontogenetic movements on strontium: calcium ratios in the otoliths of the Japanese eel, Anguilla japonica Temminck and Schlegel. J Exp Mar Biol Ecol 199:111-122

Tzeng WN, Tsai YC (1994) Changes in otolith microchemistry of the Japanese eel, Anguilla japonica, during its migration from the ocean to the rivers of Taiwan. J Fish Biol 45: 671-683

Tzeng WN, Yu SY (1986) Occurrence of the leptocephalus larvae of Elops hawaiensis and Megalops cyprinoides in the Gong-shy-tyan River estuary of north Taiwan with reference to some ecological and taxonomic aspects. Proc Symp Mar Biol Sci, Biology Research Center, Nat Sci Counc Monogr Ser 14: 165-176

> Tzeng WN, Severin KP, Wickström H (1997) Use of otolith microchemistry to investigate the environmental history of European eel Anguilla anguilla. Mar Ecol Prog Ser 149: 73-81

Tzeng WN, Wu CE, Wang YT (1998) Age of pacific tarpon, Megalops cyprinoides, at estuarine arrival and growth during metamorphosis. Zool Stud 37:177-183

Tzeng WN, Shiao JC, Iizuka Y (2002a) Use of otolith Sr:Ca ratios to study the riverine migratory behaviours of Japanese eel Anguilla japonica. Mar Ecol Prog Ser 245:213-221

Tzeng WN, Wang YT, Chang CW (2002b) Spatial and temporal variations of the estuarine larval fish community on the west coast of Taiwan. Mar Freshw Res 53:419-430

Tzeng WN, Iizuka Y, Shiao JC, Yamada Y, Oka HP (2003) Identification and growth rates comparison of divergent migratory contingents of Japanese eel (Anguilla japonica). Aquaculture 216:77-86

- Tzeng WN, Chang CW, Wang CH, Shiao JC and others (2007) Misidentification of the migratory history of anguillid eels by Sr/Ca ratios of vaterite otoliths. Mar Ecol Prog Ser 348: 285-295

Wade RA (1962) The biology of the tarpon, Megalops atlanticus, and the oxeye, Megalops cyprinoides, with emphasis on larval development. Bull Mar Sci Gulf Caribb 12: $545-622$

Wang HC (2002) Indicator fish species for water quality of freshwater streams in Taiwan. Annu Rep NIEA Taiwan ROC 9:207-236 (in Chinese)

Wang CH, Kuo CH, Mok HK, Lee SC (2003) Molecular phylogeny of elopomorph fishes inferred from mitochondrial 12S ribosomal RNA sequences. Zool Scr 32:231-241

Wells RMG, Baldwin J, Seymour RS, Baudinette RV, Christian K, Bennett MB (2003) Oxygen transport capacity in the airbreathing fish, Megalops cyprinoides: compensations for strenuous exercise. Comp Biochem Physiol A 134:45-53

Zeller DC, Russ GR (2000) Population estimates and size structure of Plectropomus leopardus (Pisces: Serranidae) in relation to no-fishing zones: mark-release-resighting and underwater visual census. Mar Freshw Res 51:221-228

Submitted: July 20, 2007; Accepted: May 22, 2009

Proofs received from author(s): July 20, 2009 